\title{
ATRIBUT KUALITAS PELAYANAN ANGKUTAN PUBLIK DI KOTA BANDUNG
}

\author{
Engelbertha Noviani Bria Seran ${ }^{1}$, Tri Basuki Joewono ${ }^{2}$ \\ ${ }^{1}$ Mahasiswa program Magister Teknik Sipil, Program Pascasarjana \\ Universitas Katolik Parahyangan, e-mail: engelberthabs@gmail.com \\ ${ }^{2}$ Dosen Jurusan Teknik Sipil, Fakultas Teknik, Universitas Katolik Parahyangan
}

\begin{abstract}
ABSTRAK
Angkutan publik adalah sarana transportasi yang penting dalam mendukung aktivitas dan mobilitas penduduk sehari - hari di suatu perkotaan. Menganalisis atribut kualitas pelayanan menurut persepsi pengguna perlu dilakukan dan diharapkan dapat menentukan atribut kualitas pelayanan yang menjadi prioritas untuk segera diperbaiki. Tujuan penelitian ini menganalisis kualitas pelayanan ditinjau dari tingkat kepentingan dan kepuasan pengguna angkutan publik dan untuk menentukan atribut - atribut kualitas pelayanan yang berpengaruh pada kualitas pelayanan dan menjadi prioritas. Data yang digunakan dalam penelitian ini adalah data primer dan sekunder. Metode analisis data yang digunakan adalah Importance-Satisfaction Analysis (ISA). Hasil analisis perbandingan tingkat kepentingan dan kepuasan menunjukkan bahwa pengguna semua jenis angkutan publik merasa tidak puas dengan atribut kualitas pelayanan yang dianggap penting. Dari diagram kategori tingkat kepentingan dan kepuasan menunjukkan beberapa atribut menurut persepsi pengguna angkutan publik penting tapi tidak memuaskan dan atribut yang paling membutuhkan pengembangan adalah kebersihan kendaraan, kebersihan stasiun/halte, kondisi fisik kendaraan, kenyamanan kendaraan, keamanan stasiun/halte, dan ketepatan waktu. Atribut yang termasuk dalam kategori perlu dipelihara adalah kemananan kendaraan dan keterampilan pengemudi. Atribut yang termasuk dalam kategori kurang penting adalah kondisi stasiun/halte, kenyamanan stasiun/halte, dan kemudahan biaya. Atribut yang masuk dalam kategori melebihi perkiraan adalah kemudahan mendapat informasi rute, kemudahan mengakses angkutan umum, keramahan staf, dan kemudahan mendapatkan moda.
\end{abstract}

Kata Kunci: Angkutan publik, Kualitas Pelayanan, Tingkat Kepentingan, Tingkat Kepuasan.

\begin{abstract}
Public transportation is an important transportation facilities in supporting the daily activities and mobility of citizens in urban areas. Analyzing the attribute of service quality according to the views of users is need to be done and is expected to help to determine the priority of attributes of service quality to be soon. The purpose of this study is to analyze the level of importance and satisfaction according to the public transportation users' point of view to determine the attribute that affect the service quality and the priority. The data used in this study are primary data and secondary data. Analysis method used is the Importance-Satisfaction Analysis (IPA). The result of comparative analysis of the level of importance and satisfaction showed that users of all kinds of public transport are not satisfied with the quality of service attributes that are considered important. From the categories diagram according to the level of importance and satisfaction showed some attribute types of modes according to the user perception of public transportation are important but do not satisfy and need development are attributes of the vehicle cleanliness, hygiene stations / shelter, the physical condition of the vehicle, vehicle comfort, security station/shelter, and punctuality. Attributes that are included in the category needs to be maintained is vehicle security and the skill of driver. Less important are attributes of the physical condition of the station/shelter, station/shelter comfort, and ease costs. Exceeding forecasts are attributes of the access to the route information, accessibility, friendliness of staff and access to the modes.
\end{abstract}

Keywords: Public Transport, Service Quality, Satisfaction level, Importance level. 


\section{PENDAHULUAN}

Masalah umum kota besar adalah kemacetan lalu lintas yang menjadi ciri kota kota di Negara berkembang. Kemacetan itu disebabkan oleh perencanaan sistem transportasi yang tidak mempertimbangkan efek yang dapat ditimbulkan di masa yang akan datang. Sistem transportasi publik adalah salah satu solusi untuk menjawab masalah - masalah transportasi di perkotaan. Sistem pelayanan transportasi publik adalah salah satu bentuk dari penyediaan sarana transportasi dengan kapasitas yang potensial. Transportasi publik dengan kapasitas penumpang yang besar, merupakan hal penting di kota - kota besar (Black, 1995).

Menurut TRB (1999) untuk meningkatkan kualitas pelayanan salah satu caranya adalah mengukur kesesuaian antara tingkat pelayanan yang diberikan dengan harapan harapan dari para pengguna. Kualitas dari pelayanan tergantung pada keputusan keputusan operasional yang dibuat, terutama keputusan mengenai dimana, seberapa sering, dan berapa lama sistem transportasi tersebut sebaiknya dilakukan, serta jenis pelayanan transportasi apa yang sebaiknya akan dibuat. Di samping itu, terdapat faktor faktor penghambat yang membuat masyarakat tidak memilih angkutan publik sebagai pilihan utama untuk melakukan perjalanan. Maka dari itu, sangat penting untuk memperbaharui kualitas pelayanan angkutan publik yang sesuai dengan tingkat kepentingan dan kepuasan masyarakat saat ini, sehingga dapat mempertahankan pengguna yang ada dan menarik pengguna baru. Pilihan pengguna dalam memanfaatkan transportasi publik tergantung pada persepsi dan preferensi mereka. Persepsi pengguna jasa yang ada dibangun dari pengalaman mereka dalam memanfaatkan pelayanan tersebut. Luasnya pengalaman dengan menggunakan pelayanan juga dapat mempengaruhi tingkat harapan pengguna (Joewono and Kubota, 2005).

Penelitian ini bertujuan menganalisis tingkat kepuasan dan tingkat kepentingan dari atribut - atribut kualitas pelayanan berdasarkan persepsi pengguna untuk meningkatkan kualitas sistem pelayanan angkutan publik, maka atribut yang menjadi prioritas harus segera diperbaiki. Tingkat kebutuhan angkutan publik hanya ditinjau dari sisi pengguna saja, sedangkan dari sisi yang lain seperti operator, pengambil keputusan tidak ditinjau. Atribut kualitas pelayanan yang ditinjau adalah waktu tempuh, ketepatan waktu, waktu tunggu, keamanan dalam kendaraan, keamanan di halte/stasiun, kenyamanan, kebersihan dalam kendaraan, kebersihan halte/stasiun, keselamatan, kemudahan mendapatkan dan kelengkapan informasi, lokasi halte/stasiun, tarif, dan kualitas pelayanan staff (keramahan dan pelayanan). Metode analisis yang digunakan adalah Importance - Satisfaction Analysis (ISA) dengan diagram kategori. 


\section{KUALITAS PELAYANAN ANGKUTAN PUBLIK}

Kualitas pelayanan yang dirasakan oleh pengguna angkutan publik dapat didefinisikan sebagai tingkat perbedaan antara harapan dan keinginan pengguna. Hal ini berarti kualitas pelayanan, sebagaimana yang dirasakan oleh pengguna angkutan publik, didefinisikan sebagai tingkat ketidaksesuaian antara harapan dan keinginan pengguna dan persepsi mereka (Zeithaml et al., 1990).

Dalam hal peningkatan kualitas pelayanan maka tidak semua atribut bisa mencapai efek yang sama, karena dilihat dari sudut pandang pengguna tidak semua atribut kualitas pelayanan sama penting bagi pengguna angkutan publik. Maka perlu untuk mengidentifikasi atribut - atribut kualitas pelayanan mana saja yang perlu perbaikan. Penilaian mengenai tingkat kepentingan dan tingkat kepuasan pengguna dengan atribut atribut kualitas pelayanan dapat membantu perencana transportasi dan pembuat kebijakan untuk mengevaluasi dan menentukan atribut - atribut yang utama yang memerlukan perbaikan (Dragana et al, 2013).

Survei tingkat kepentingan dan kepuasan berdasarkan persepsi pengguna dilakukan dengan cara mengukur kualitas pelayanan melalui metode Importance Satisfaction Analysis (ISA), dimana responden diminta untuk merangking berbagai atribut dari penawaran berdasarkan tingkat kepentingan dan tingkat kepuasan mereka terhadap setiap atribut tersebut. Selain itu responden juga diminta untuk merangking seberapa baik atribut kualitas pelayanan angkutan publik dari masing - masing jenis moda angkutan publik (Yurtseven, 2006).

Pengukuran kepuasan pengguna angkutan publik ini sangat penting dilakukan, karena dapat memberikan masukan pada pemilik jasa atau mereka yang berkepentingan dalam membuat kebijakan, sekaligus dapat membuat pengguna angkutan publik merasa diperhatikan. Perhatian ini akan membuat pengguna merasa dihargai, yang pada akhirnya dapat memenuhi harapan dan kepuasan pengguna.

Penilaian importance-satisfaction (IS) dihitung dengan mengalikan nilai kepentingan dengan 1 (satu) dikurangi nilai kepuasan, seperti yang ditunjukkan pada persamaan 2.1.

$$
\text { IS }=\text { importance } x(1-\text { satisfaction })=\text { importance } x \text { dissatisfaction }
$$

Dengan: Importance $\quad=$ Persentase responden yang menjawab penting.

Satisfaction $\quad=$ Persentase responden yang menjawab puas.

Hasil dari analisis ini menunjukkan atribut - atribut yang memenuhi tingkat kepentingan dan kepuasan pengguna angkutan publik dan fasilitas yang paling membutuhkan perbaikan berdasarkan proporsi yang didapat. Setelah persentase IS didapat kemudian 
nilai tersebut diplot pada diagram kategori yang terdiri dari 4 kategori yaitu perlu pemeliharaan, melebihi perkiraan, kurang penting, dan membutuhkan pengembangan. Keempat kategori tersebut dibagi oleh garis rata - rata tingkat kepentingan dan kepuasan yang didapat dari hasil pengumpulan data (Yurtseven, 2006 dalam Gultom, 2011). Diagram kategori tingkat kepentingan dan kepuasan dapat dilihat pada gambar 2.3.

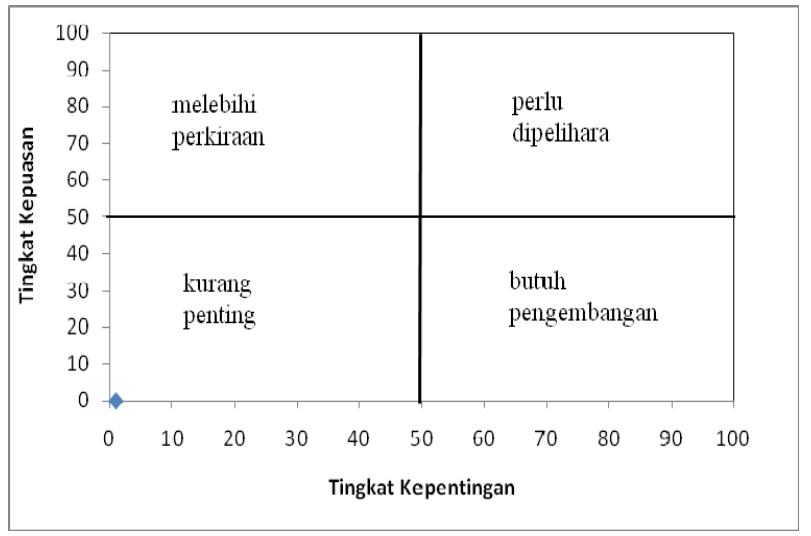

Gambar 1 Diagram Kategori Tingkat Kepentingan Dan Kepuasan (Yurtseven, 2006)

\section{PENGUMPULAN DATA}

Populasi penelitian ini adalah penguna jasa angkutan publik di kota Bandung. Dalam menentukan besarnya sampel penelitian digunakan metode penentuan sampel cluster random sampling. Dengan e $=0,05$ dan jumlah populasi 23.283.215 maka untuk menentukan ukuran sampel digunakan rumus Yamane, (1967) dalam Israel, (1992). Dari hasil perhitungan didapatkan ukuran sampel yang dibutuhkan adalah 400 responden. Untuk memenuhi batas minimal sampel, maka ukuran tersebut ditambah menjadi 420 responden.

Pengumpulan data dilakukan dengan penyebaran kuesioner di kota Bandung yang terbagi menjadi enam wilayah sebagai berikut: wilayah Cibeunying (1), wilayah Ujungberung (2), wilayah Gede Bage (3), wilayah Karees (4), wilayah Tegallega (5), dan wilayah Bojonagara (6). Penomoran enam wilayah kota Bandung dilakukan oleh surveyor untuk mempermudah pada saat survei. Penyebaran kuesioner dilakukan dengan tiga surveyor mulai dari tanggal 27 April 2015 - 4 Mei 2015 dan waktu penyebaran dari pagi hingga sore hari. Survei dilakukan pada hari kerja dan hari libur (libur nasional dan hari minggu) di tempat - tempat keramaian seperti mall, sekolah, perkantoran, taman, pusat perdagangan, dan area makan.

Dalam kuesioner penelitian terhadap kualitas pelayanan angkutan publik ini ada lima bagian yang akan dipertanyakan, yaitu: 
1. Karakteristik perjalanan dengan angkutan publik. Misalnya menggunakan moda transportasi apa, tujuannya dan seberapa sering menggunakan angkutan publik.

2. Data umum pengguna angkutan publik. Misalnya usia pengguna, jenis kelamin, dan pekerjaan.

3. Pengalaman buruk, responden diminta untuk menjelaskan pengalaman yang tidak menyenangkan selama menggunakan angkutan publik dan seberapa sering itu terjadi.

4. Evaluasi. Dalam evaluasi ini akan di tinjau tingkat kepuasan dan kepentingan dengan metode skala pengukuran dari 1 sampai 4.

5. Masa depan. Responden diminta untuk menentukan keputusan yang akan diambil jika ada perubahan pada kondisi angkutan publik.

Jumlah responden yang terbanyak adalah dari wilayah Cibeunying sebesar 104 responden, diikuti wilayah Karees 75 . Wilayah Tegallega dan wilayah Bojonagara memiliki jumlah responden yang kurang lebih hampir sama yaitu 67 dan 62. Untuk lokasi survei yang spesifik dan jumlah responden dapat dilihat di Tabel 4.1 dan gambaran umum wilayah kota Bandung dapat dilihat pada Gambar 4.1.

\section{DATA DAN ANALISIS}

\subsection{Deskripsi Karakteristik Responden}

Distribusi usia responden pengguna angkutan publik menurut jenis moda terbagi dalam lima jenis moda dan lima kelompok usia seperti terlihat dalam Tabel 2. Yang paling dominan adalah pengguna yang berusia antara 18 hingga 29 tahun dengan persentase diatas $50 \%$ dan pengguna terbanyak adalah pada moda kereta api. Pada Tabel 3 dapat dilihat pengguna angkutan publik menurut jenis moda paling dominan adalah pria pada jenis moda kereta api sebesar $86,7 \%$ dan $60 \%$ pada jenis moda taksi. Hal ini menunjukkan pria sebagai kepala keluarga dan pencari nafkah lebih cenderung melakukan perjalanan dengan jarak panjang dan mengutamakan keefisienan. Sedangkan wanita lebih cenderung menggunakan angkutan publik jenis angkot dan bis.

Tabel 2 Distribusi Usia Responden Menurut Jenis Moda

\begin{tabular}{lrrrrr}
\hline Jenis Moda & \multicolumn{5}{c}{ Usia (\%) } \\
\cline { 2 - 6 } & $<\mathbf{1 7}$ Tahun & $\begin{array}{c}\mathbf{1 8 - 2 9} \\
\text { Tahun }\end{array}$ & $\begin{array}{c}\mathbf{3 0 - 3 9} \\
\text { Tahun }\end{array}$ & $\begin{array}{c}\mathbf{4 0 - 4 9} \\
\text { Tahun }\end{array}$ & $\begin{array}{r}\mathbf{5 0 - 6 5} \\
\text { Tahun }\end{array}$ \\
\hline Angkot & 6,4 & 70,1 & 14,8 & 4,4 & 4,0 \\
Bis & 7,1 & 53,6 & 25,0 & 7,1 & 7,1 \\
Kereta Api & 6,7 & 73,3 & 20,0 & 0,0 & 0,0 \\
Taksi & 2,2 & 71,1 & 13,3 & 11,1 & 2,2 \\
Lainnya & 21,4 & 57,1 & 14,3 & 7,1 & 0,0 \\
\hline
\end{tabular}


Tabel 3 Jenis Kelamin Pengguna Angkutan Publik Menurut Jenis Moda

\begin{tabular}{|c|c|c|}
\hline \multirow[b]{2}{*}{ Jenis Moda } & \multicolumn{2}{|c|}{ Jenis Kelamin } \\
\hline & $\begin{array}{l}\text { Pria } \\
(\%)\end{array}$ & $\begin{array}{c}\text { Wanita } \\
(\%) \\
\end{array}$ \\
\hline Angkot & 38,6 & 61,4 \\
\hline Bis & 42,9 & 57,1 \\
\hline KA & 86,7 & 13,3 \\
\hline Taksi & 60 & 35,6 \\
\hline Lainnya & 35,7 & 64,3 \\
\hline
\end{tabular}

Tabel 4 Penghasilan per Bulan Pengguna Angkutan Publik Menurut Jenis Moda

\begin{tabular}{|c|c|c|c|c|c|c|}
\hline \multirow{2}{*}{$\begin{array}{l}\text { Jenis } \\
\text { Moda }\end{array}$} & \multicolumn{6}{|c|}{ Penghasilan perbulan } \\
\hline & $\begin{array}{l}<\mathbf{R p} \\
\mathbf{5 0 0 . 0 0 0}\end{array}$ & $\begin{array}{l}\text { Rp } \\
500.001- \\
\operatorname{Rp} \\
\mathbf{1 . 0 0 0 . 0 0 0}\end{array}$ & $\begin{array}{l}\text { Rp } \\
1.000 .001 \\
-\mathbf{R p} \\
2.500 .000\end{array}$ & $\begin{array}{l}\text { Rp } \\
2.500 .001 \\
-\mathbf{R p} \\
5.000 .000\end{array}$ & $\begin{array}{l}\text { Rp } \\
5.000 .001 \\
-\mathbf{R p} \\
7.500 .000\end{array}$ & $\begin{array}{l}>\text { Rp } \\
7.500 .001\end{array}$ \\
\hline Angkot & 12,4 & 21,5 & 34,2 & 26,5 & 3,4 & 2,0 \\
\hline Bis & 10,7 & 3,6 & 35,7 & 32,1 & 10,7 & 7,1 \\
\hline KA & 20,0 & 20,0 & 33,3 & 20,0 & 6,7 & 0,0 \\
\hline Taksi & 6,7 & 4,4 & 22,2 & 40,0 & 15,6 & 11,1 \\
\hline Lainnya & 14,3 & 14,3 & 21,4 & 42,9 & 7,1 & 0,0 \\
\hline
\end{tabular}

Pada Tabel 4 rata - rata penguna angkutan publik jenis angkot, bis dan kereta api adalah responden yang berpenghasilan $\mathrm{Rp} 1.000 .001$ - Rp 2.500.000 dengan proporsi $34,2 \%, 35,7 \%$, dan 33,3\%. Sedangkan pengguna moda taksi sebesar $40 \%$ berpenghasilan Rp 2.500.001 - Rp 5.000.000.

Karakteristik sosio demografi pengguna angkutan publik di kota Bandung dapat dilihat bahwa hampir sebagian responden dari kelima jenis moda memiliki status belum atau pernah menikah dengan rata - rata proporsi $77 \%$. Kondisi rumah tangga para responden didominasi oleh responden yang tinggal sendiri dengan proporsi 29,5\% pengguna angkot, $28,6 \%$ pengguna bis, dan $37,8 \%$ penguna taksi. Sebanyak $60,1 \%$ responden pengguna angkot berkedudukan sebagai anak di dalam keluarganya dan 54,7\% pelajar/mahasiswa adalah pengguna angkot. Hal ini menunjukkan bahwa pelajar/mahasiswa lebih memilih menggunakan angkot karena biaya yang terjangkau dan jarak yang pendek misalnya untuk mahasiswa yang lebih banyak melakukan perjalanan dari kontrakan menuju kampus.

Dilihat dari pendidikan terakhir $48,7 \%$ pengguna angkot adalah yang berpendidikan SMA (setingkat) dan yang berpendidikan S1 53,6\% menggunakan bis. Sedangkan pengguna angkot $2,7 \%$ adalah yang berpendidikan S2/S3. Hal ini dapat disebabkan dari tingkat pendidikan seseorang yang jika semakin tinggi pendidikannya 
semakin berpengaruh pola pikirnya maka yang berpendidikan tinggi lebih memilih menggunakan kendaraan pribadi dibandingkan angkutan publik. Selain dari kemampuan segi ekonomi dan tujuan perjalanan, menggunakan kendaraan pribadi dirasa lebih aman dan privasi. Pengguna angkot yang tidak sekolah atau SD (sekolah dasar) proporsinya kurang dari $10 \%$ yaitu sebesar $0,3 \%$. Hal ini dikarenakan pengguna hanya menggunakan angkutan publik bila diperlukan, dengan kata lain jika masih bisa ditempuh dengan berjalan kaki maka akan lebih memilih jalan kaki. Alokasi biaya perjalanan yang dikeluarkan oleh responden pengguna taksi adalah kurang dari 10\% dan sekitar 11\% $20 \%$ dari penghasilan yang diperoleh, dengan proporsi yang sama yaitu $40 \%$.

Data karakteristik rumah tangga responden menunjukkan bahwa hampir sebagian besar responden tinggal di rumah milik orang tua mereka dengan proporsi $47,7 \%$ pengguna angkot, 39,3\% pengguna bis, 53,3\% pengguna kereta api, dan 37,8\% pengguna taksi. Sedangkan $44 \%$ pengguna angkot tidak memiliki mobil dan rata - rata diatas $40 \%$ pengguna bis, kereta api, dan taksi memiliki 1 unit mobil. Sedangkan rata - rata 28\% $40 \%$ pengguna angkutan publik memiliki 1 - 2 unit motor dan terdapat $71,4 \%$ pengguna bis yang tidak memiliki kendaraan tidak bermotor. Untuk kepemilikan Surat Izin Mengemudi sebesar $44 \%$ pengguna angkot dan $60,7 \%$ pengguna bis tidak memiliki Surat Izin Mengemudi. Sedangkan 44,4\% pengguna taksi memiliki lebih dari satu jenis SIM.

\subsection{Deskripsi Karakteristik Perjalanan Responden}

Dari hasil deskripsi jumlah pengguna angkutan publik di kota Bandung biasa menggunakan angkot sebagai moda angkutan publik yang biasa digunakan dengan jumlah penggunaannya sebesar $74 \%$. Tujuan perjalanan responden di kota Bandung terbesar adalah menuju sekolah dan bekerja menggunakan angkot dengan proporsi 37,2\% dan $30,9 \%$ dan menggunakan bis dengan proporsi $39,3 \%$ dan 35,7\%. Sedangkan untuk pergi berbelanja responden lebih cenderung menggunakan taksi dengan proporsi $24,4 \%$.

Distribusi penggunaan angkutan publik dalam satu hari kerja diketahui sebagian besar responden adalah pengguna angkutan publik bis sebesar $67,9 \%$ dengan frekuensi dua kali dalam satu hari kerja. Sedangkan pengguna angkot dan taksi menggunakan angkutan publik sebanyak satu hingga dua kali dalam satu hari kerja dengan proporsi $48,9 \%$ dan 49,7\%. Penggunaan angkutan publik dalam satu minggu mayoritas responden menggunakan angkutan publik angkot, bis, dan kereta api sebanyak tiga kali atau lebih dengan rata - rata proporsi $58 \%$.

Penggunaan angkutan publik pada hari libur menunjukkan sebagian responden tidak menggunakan angkutan publik pada hari libur. Sedangkan $31,1 \%$ responden menggunakan taksi dan $28,9 \%$ menggunakan angkot pada hari libur. Alasan 
menggunakan angkutan publik dengan proporsi $42,9 \%$ pengguna bis dan $36,6 \%$ pengguna angkot karena tidak memiliki kendaraan pribadi. Namun sebagian responden dengan proporsi dibawah 30\% memberikan alasan lain seperti lebih murah, cepat, praktis, mudah penggunaannya, dan mudah mendapatkannya. Sedangkan $46,4 \%$ responden pengguna bis dan $42,2 \%$ pengguna taksi tidak menggunakan angkutan publik dengan alasan kondisi lalu lintas tidak mendukung. Sementara $40 \%$ pengguna kereta api tidak menggunakan angkutan publik karena alasan kondisi cuaca tidak mendukung dan 34,2\% pengguna angkot memberikan alasan karena kondisi lalu-lintas tidak mendukung.

\subsection{Deskripsi Pengalaman Buruk Responden}

Dilihat dari pengalaman buruk yang dialami oleh responden di kota Bandung, 73,3\% responden pengguna kereta api sering mengalami pengalaman buruk menunggu angkutan publik yang dikehendaki. Proporsi yang besar untuk pengalaman buruk menunggu juga sering dialami pengguna angkot dan taksi yaitu sebesar 56,4\% dan $53,3 \%$. Pengalaman buruk terlambat juga sering terjadi pada pengguna angkot dan kereta api dengan proporsi $49,7 \%$ dan $66,7 \%$. Rata- rata $66,8 \%$ pengguna semua jenis moda angkutan publik sangat sering mengalami pengalaman buruk kecelakaan dan 68,3\% pengguna semua jenis moda angkutan publik sangat sering kehilangan barang. Sedangkan $56,4 \%$ pengguna angkot dan $66,7 \%$ pengguna kereta api sering mengalami pengalaman buruk masalah pembayaran. Pengalaman buruk mengenai informasi biaya, rute dan jadwal sering dialami pengguna kereta api $60 \%$ dan pengguna angkot $54,2 \%$. Terdapat $67,8 \%$ responden pengguna angkot yang sering mengalami kesulitan akibat supir angkutan publik merubah rute dari seharusnya.

Hasil analisis menunjukkan terdapat perbedaan persepsi pengguna tentang pengalaman buruk pada beberapa pengalaman. Studi lebih lanjut mengenai pengalaman buruk pengguna angkutan publik dapat bermanfaat dalam menyediakan pelayanan yang lebih tepat sasaran dan semakin baik. Hal ini juga berguna untuk memperkirakan penggunaan angkutan publik di masa yang akan datang dan untuk mengurangi pengalaman buruk yang dialami penggunanya.

Pendapat pengguna tentang kualitas angkutan publik adalah jika kualitas pelayanan tetap dan biaya tetap maka $85,7 \%$ pengguna bis dan $75,8 \%$ pengguna angkot akan tetap menggunakan angkutan publik. Sebagian besar responden memilih tetap akan menggunakan angkutan publik jika kebersihan, skill pengemudi, armada, keamanan, dan kenyamanan ditingkatkan tetapi biaya ditingkatkan. Sedangkan jika biaya diturunkan dan kenyamanan diturunkan maka $72,5 \%$ responden memilih pindah ke moda yang lain. 


\subsection{Deskripsi Tingkat Kepentingan}

Hasil deskripsi data tingkat kepentingan menurut jenis moda dapat dilihat bahwa mayoritas responden memilih pilihan jawaban "sangat penting" dan "penting". Hal ini berarti tingkat kepentingan pengguna terhadap seluruh atribut kualitas pelayanan moda angkutan publik adalah tinggi. Deskripsi tingkat kepentingan menurut masing - masing moda angkutan publik maka dilakukan analisis deskriptif dan analisis nonparametric test k-related samples yaitu metode Friedman test (Siegel, 1992). Untuk menguji hipotesis keberadaan perbedaan penilaian untuk setiap atribut kualitas pelayanan moda angkutan publik. Hipotesis yang digunakan dalam uji ini adalah $\mathrm{H}_{0}$ :Tidak terdapat perbedaan penilaian responden antar atribut kualitas pelayanan moda angkutan public, dan $\mathrm{H}_{1}$ terdapat perbedaan penilaian responden antar atribut kualitas pelayanan moda angkutan publik. Pada Tabel 5 dapat dilihat sebagian besar responden pengguna angkot menilai seluruh atribut kualitas pelayanan sangat penting dan penting pada atribut kondisi stasiun/halte sebesar 41,6\%, kemudahan biaya sebesar 45,6\%, dan atribut moda $40,3 \%$. Sedangkan sebanyak $0,3 \%$ responden pengguna angkot menilai atribut keterampilan pengemudi dan kemudahan mendapatkan moda adalah sangat tidak penting. Dari hasil analisis tingkat kepentingan menurut pengguna angkot dapat dilihat bahwa p-value yang didapatkan adalah lebih kecil dari tingkat signifikansi yang digunakan $(\alpha=0,05)$. Hasil ini menjelaskan bahwa responden menilai seluruh atribut kualitas pelayanan moda angkutan publik sebagai berbeda. Hal ini juga berarti setiap atribut memiliki pengaruh terhadap responden untuk menentukan kategori jawaban yang akan dipilih.

Sebagian besar responden pengguna bis menilai seluruh atribut kualitas pelayanan sangat penting, kecuali atribut kondisi stasiun/halte, kenyamanan kendaraan, dan kenyamanan stasiun/halte menurut persepsi pengguna bis adalah penting. Dari hasil analisis tingkat kepentingan menurut pengguna bis dapat dilihat bahwa p-value yang didapatkan adalah lebih besar dari tingkat signifikansi yang digunakan $(\alpha=0,05)$. Hasil ini menjelaskan bahwa tidak terdapat perbedaan responden pengguna bis dalam menilai seluruh atribut kualitas pelayanan moda angkutan publik. Artinya setiap atribut tidak memiliki pengaruh satu sama lain terhadap responden untuk menentukan kategori jawaban yang akan dipilih. 
Tabel 5 Deskripsi Data Tingkat Kepentingan Menurut Pengguna

\begin{tabular}{|c|c|c|c|c|c|c|c|c|c|c|c|c|c|c|c|c|c|c|c|c|}
\hline \multirow{3}{*}{$\begin{array}{l}\text { Atribut } \\
\text { Kualitas } \\
\text { Pelyanan }\end{array}$} & \multicolumn{20}{|c|}{ Proporsi (\%) } \\
\hline & \multicolumn{4}{|c|}{ Angkot } & \multicolumn{4}{|c|}{ Bis } & \multicolumn{4}{|c|}{ Kereta Api } & \multicolumn{4}{|c|}{ Taksi } & \multicolumn{4}{|c|}{ Lainnya } \\
\hline & $\begin{array}{l}\text { SP } \\
(\%) \\
\end{array}$ & $\begin{array}{l}\mathbf{P} \\
(\%) \\
\end{array}$ & $\begin{array}{l}\text { TP } \\
(\%) \\
\end{array}$ & $\begin{array}{l}\text { STP } \\
(\%) \\
\end{array}$ & $\begin{array}{l}\text { SP } \\
(\%)\end{array}$ & $\begin{array}{l}\mathbf{P} \\
(\%) \\
\end{array}$ & $\begin{array}{l}\text { TP } \\
(\%)\end{array}$ & $\begin{array}{l}\text { STP } \\
(\%) \\
\end{array}$ & $\begin{array}{l}\text { SP } \\
(\%)\end{array}$ & $\begin{array}{l}\mathbf{P} \\
(\%)\end{array}$ & $\begin{array}{l}\text { TP } \\
(\%) \\
\end{array}$ & $\begin{array}{l}\text { STP } \\
(\%) \\
\end{array}$ & $\begin{array}{l}\text { SP } \\
(\%)\end{array}$ & $\begin{array}{l}\mathbf{P} \\
(\%)\end{array}$ & $\begin{array}{l}\text { TP } \\
(\%) \\
\end{array}$ & $\begin{array}{l}\text { STP } \\
(\%) \\
\end{array}$ & $\begin{array}{l}\text { SP } \\
(\%)\end{array}$ & $\begin{array}{l}\mathbf{P} \\
(\%)\end{array}$ & $\begin{array}{l}\text { TP } \\
(\%) \\
\end{array}$ & $\begin{array}{l}\text { STP } \\
(\%) \\
\end{array}$ \\
\hline $\begin{array}{l}\text { Kebersihan } \\
\text { Kendaraan } \\
\text { Kebersihan }\end{array}$ & 56,0 & 43,6 & 0,3 & 0 & 60,7 & 39,3 & 0 & 0 & 53,3 & 46,7 & 0,0 & 0 & 75,6 & 24,4 & 0,0 & 0 & 64,3 & 35,7 & 0 & 0 \\
\hline $\begin{array}{l}\text { Stasiun/Halte } \\
\text { Kondisi }\end{array}$ & 53,7 & 45,0 & 1,3 & 0 & 50,0 & 50,0 & 0 & 0 & 46,7 & 53,3 & 0,0 & 0 & 66,7 & 31,1 & 2,2 & 0 & 50,0 & 50,0 & 0 & 0 \\
\hline $\begin{array}{l}\text { Kendaraan } \\
\text { Kondisi }\end{array}$ & 58,1 & 40,6 & 1,3 & 0 & 60,7 & 39,3 & 0 & 0 & 46,7 & 53,3 & 0,0 & 0 & 66,7 & 31,1 & 2,2 & 0 & 50,0 & 50,0 & 0 & 0 \\
\hline $\begin{array}{l}\text { Stasiun/Halte } \\
\text { Kenyamanan }\end{array}$ & 41,6 & 54,0 & 4,4 & 0 & 39,3 & 60,7 & 0 & 0 & 33,3 & 60,0 & 6,7 & 0 & 51,1 & 44,4 & 4,4 & 0 & 50,0 & 50,0 & 0 & 0 \\
\hline $\begin{array}{l}\text { Kendaraan } \\
\text { Kenyamanan }\end{array}$ & 66,1 & 33,9 & 0,0 & 0 & 39,3 & 60,7 & 0 & 0 & 46,7 & 46,7 & 6,7 & 0 & 77,8 & 22,2 & 0,0 & 0 & 71,4 & 28,6 & 0 & 0 \\
\hline $\begin{array}{l}\text { Stasiun/Halte } \\
\text { Kemudahan }\end{array}$ & 50,0 & 47,7 & 2,3 & 0 & 46,4 & 53,6 & 0 & 0 & 26,7 & 66,7 & 6,7 & 0 & 55,6 & 42,2 & 2,2 & 0 & 57,1 & 42,9 & 0 & 0 \\
\hline $\begin{array}{l}\text { Rute } \\
\text { Kemudahan }\end{array}$ & 54,7 & 41,9 & 3,4 & 0 & 57,1 & 42,9 & 0 & 0 & 53,3 & 40,0 & 6,7 & 0 & 60,0 & 40,0 & 0,0 & 0 & 57,1 & 35,7 & 7,1 & 0 \\
\hline $\begin{array}{l}\text { Biaya } \\
\text { Keamanan di }\end{array}$ & 45,6 & 50,3 & 4,0 & 0 & 67,9 & 28,6 & 3,6 & 0 & 46,7 & 53,3 & 0,0 & 0 & 53,3 & 44,4 & 2,2 & 0 & 50,0 & 50,0 & 0 & 0 \\
\hline $\begin{array}{l}\text { Kendaraan } \\
\text { Keamanan di }\end{array}$ & 80,2 & 19,5 & 0,3 & 0 & 85,7 & 14,3 & 0 & 0 & 80,0 & 20,0 & 0,0 & 0 & 86,7 & 13,3 & 0,0 & 0 & 85,7 & 14,3 & 0 & 0 \\
\hline $\begin{array}{l}\text { Stasiun } \\
\text { Kemudahan }\end{array}$ & 73,2 & 25,5 & 1,3 & 0 & 64,3 & 35,7 & 0 & 0 & 53,3 & 46,7 & 0,0 & 0 & 71,1 & 26,7 & 2,2 & 0 & 71,4 & 28,6 & 0 & 0 \\
\hline $\begin{array}{l}\text { Akses } \\
\text { Keterampilan }\end{array}$ & 52,0 & 46,3 & 1,7 & 0 & 50,0 & 46,4 & 3,6 & 0 & 60,0 & 33,3 & 6,7 & 0 & 62,2 & 35,6 & 2,2 & 0 & 64,3 & 35,7 & 0 & 0 \\
\hline Pengemudi & 68,1 & 30,9 & 0,7 & 0,3 & 57,1 & 39,3 & 3,6 & 0 & 60,0 & 40,0 & 0,0 & 0 & 68,9 & 28,9 & 2,2 & 0 & 57,1 & 42,9 & 0 & 0 \\
\hline Tepat Waktu & 63,4 & 36,2 & 0,3 & 0 & 60,7 & 39,3 & 0 & 0 & 60,0 & 40,0 & 0,0 & 0 & 73,3 & 26,7 & 0,0 & 0 & 64,3 & 35,7 & 0 & 0 \\
\hline Keramahan & 51,7 & 46,0 & 2,3 & 0 & 53,6 & 46,4 & 0 & 0 & 33,3 & 60,0 & 6,7 & 0 & 48,9 & 48,9 & 2,2 & 0 & 64,3 & 35,7 & 0 & 0 \\
\hline Moda & 40,3 & 58,1 & 1,3 & 0,3 & 60,7 & 35,7 & 3,6 & 0 & 26,7 & 66,7 & 6,7 & 0 & 51,1 & 46,7 & 2,2 & 0 & 42,9 & 57,1 & 0 & 0 \\
\hline $\mathrm{N}$ & & & & 298 & & & & 28 & & & & 15 & & & & 45 & & & & 14 \\
\hline Chi-Square & & & & 44,613 & & & & 23,057 & & & & 29,712 & & & & 52,659 & & & & 16,821 \\
\hline Df & & & & 14 & & & & 14 & & & & 14 & & & & 14 & & & & 14 \\
\hline p-value & & & & 0,000 & & & & 0,059 & & & & 0,008 & & & & 0,000 & & & & 0,266 \\
\hline
\end{tabular}

Keterangan : $\quad \mathrm{SP}=$ Sangat Penting; $\mathrm{P}=$ Penting; $\mathrm{TP}=$ Tidak Penting; $\mathrm{STP}=$ Sangat Tidak Penting 
Deskripsi tingkat kepentingan menurut pengguna kereta api sebagian besar memiliki penilaian yang sama besar terhadap seluruh atribut kualitas pelayanan yaitu sangat penting dan penting. Dari hasil analisis tingkat kepentingan menurut pengguna kereta api dapat dilihat bahwa $p$-value yang didapatkan adalah lebih kecil dari tingkat signifikansi yang digunakan $(\alpha=0,05)$. Hasil ini menjelaskan bahwa responden menilai seluruh atribut kualitas pelayanan moda angkutan publik sebagai berbeda. Hal ini juga berarti setiap atribut memiliki pengaruh terhadap responden pengguna kereta api untuk menentukan kategori jawaban yang akan dipilih.

Sedangkan menurut pengguna taksi rata - rata $64,6 \%$ responden pengguna taksi menilai seluruh atribut kualitas pelayanan sangat penting. Dari hasil analisis tingkat kepentingan menurut pengguna taksi dapat dilihat bahwa $p$-value yang didapatkan adalah lebih kecil dari tingkat signifikansi yang digunakan $(\alpha=0,05)$. Hasil ini menjelaskan bahwa responden menilai seluruh atribut kualitas pelayanan moda angkutan publik sebagai berbeda. Analisis menunjukkan bahwa setiap atribut memiliki pengaruh terhadap responden untuk menentukan kategori jawaban yang akan dipilih.

Deskripsi data tingkat kepentingan menurut pengguna moda angkutan publik lainnya menunjukkan sebagian besar responden pengguna angkutan publik lainnya menilai seluruh atribut kualitas pelayanan sangat penting dan penting, kecuali dua atribut yang memiliki proporsi rendah adalah atribut kenyamanan kendaraan dan keamanan di stasiun dengan proporsi yang sama $28,6 \%$ responden menilai penting. Atribut kemudahan rute sebesar $7.1 \%$ menilai tidak penting, dikarenakan jenis angkutan publik lainnya seperti ojek dan becak tidak memerlukan rute. Dari hasil analisis tingkat kepentingan menurut pengguna angkutan publik lainnya dapat dilihat bahwa $p$-value yang didapatkan adalah lebih besar dari tingkat signifikansi yang digunakan $(\alpha=0,05)$. Hasil ini menjelaskan bahwa tidak terdapat perbedaan responden pengguna angkutan publik lainnya dalam menilai seluruh atribut kualitas pelayanan. Artinya setiap atribut tidak memiliki pengaruh satu sama lain terhadap responden untuk menentukan kategori jawaban yang akan dipilih.

Menganalisis persepsi responden antar moda terhadap atribut kualitas pelayanan dilakukan untuk mengetahui berdasarkan tingkat kepentingan apakah terdapat perbedaan persepsi pengguna masing - masing moda angkutan publik terhadap atribut kualitas pelayanan publik. Analisis yang digunakan adalah metode Kruskal Wallis. Hipotesis yang digunakan adalah:

$\mathrm{H}_{0}$ : Penilaian responden pada setiap atribut kualitas pelayanan antar moda angkutan publik adalah tidak berbeda. 
$\mathrm{H}_{1}$ : Penilaian responden pada setiap atribut kualitas pelayanan antar moda angkutan publik adalah berbeda.

Hasil analisis kruskal wallis pada Tabel 6 menunjukkan bahwa p-value yang didapat dari hasil perhitungan lebih besar dari tingkat signifikansi $(\alpha)$ yang digunakan, yaitu 0,05 . Berdasarkan analisis tersebut bahwa tidak terdapat perbedaan persepsi pengguna antar moda terhadap atribut kualitas pelayanan angkutan publik. Dengan demikian penilaian responden antar moda tentang tingkat kepentingan atribut kualitas pelayanan tidak terkait. Hasil penelitian berdasarkan tingkat kepentingan ini juga menjelaskan bahwa perhatian terhadap atribut - atribut kualitas pelayanan tersebut adalah penting, karena sebagian atribut yang dianggap penting masih dinilai tidak memuaskan. Analisis lebih lanjut yang menunjukkan peran dari masing - masing atribut perlu dilakukan untuk menentukan prioritas perbaikan yang sesuai harapan pengguna.

Tabel 6 Analisis Persepsi Responden Antar Moda Terhadap Atribut Kualitas Pelayanan Berdasarkan Tingkat Kepentingan

\begin{tabular}{lrc}
\hline Atribut Kualitas Pelayanan & P-Value & Keterangan \\
\hline Kebersihan Kendaraan & 0,164 & $\mathrm{H}_{0}$ diterima \\
Kebersihan Stasiun/Halte & 0,515 & $\mathrm{H}_{0}$ diterima \\
Kondisi Kendaraan & 0,621 & $\mathrm{H}_{0}$ diterima \\
Kondisi Stasiun/Halte & 0,738 & $\mathrm{H}_{0}$ diterima \\
Kenyamanan Kendaraan & 0,170 & $\mathrm{H}_{0}$ diterima \\
Kenyamanan Stasiun/Halte & 0,359 & $\mathrm{H}_{0}$ diterima \\
Kemudahan Rute & 0,922 & $\mathrm{H}_{0}$ diterima \\
Kemudahan Biaya & 0,236 & $\mathrm{H}_{0}$ diterima \\
Keamanan di Kendaraan & 0,708 & $\mathrm{H}_{0}$ diterima \\
Keamanan di Stasiun & 0,512 & $\mathrm{H}_{0}$ diterima \\
Kemudahan Akses & 0,686 & $\mathrm{H}_{0}$ diterima \\
Keterampilan Pengemudi & 0,631 & $\mathrm{H}_{0}$ diterima \\
Tepat Waktu & 0,739 & $\mathrm{H}_{0}$ diterima \\
Keramahan & 0,517 & $\mathrm{H}_{0}$ diterima \\
Moda & 0,138 & $\mathrm{H}_{0}$ diterima \\
\hline
\end{tabular}

\subsection{Deskripsi Tingkat Kepuasan}

Deskripsi tingkat kepuasan menunjukan mayoritas responden memilih pilihan jawaban "puas" dan "tidak puas". Hal ini berarti tingkat kepuasan seluruh atribut kualitas pelayanan moda angkutan publik termasuk dalam kategori cukup, proporsi pilihan jawaban puas tertinggi yaitu $73,3 \%$ pengguna taksi dari atribut kemudahan akses dan moda. Pengguna angkot juga menilai atribut kemudahan akses dan moda sebagai puas dengan proporsi $57,4 \%$ dan $57,7 \%$, sedangkan proporsi pilihan jawaban puas terendah pengguna angkutan publik lainnya diperoleh dari atribut kebersihan stasiun/halte $(9,1 \%)$. Penilaian "puas" pada atribut keterampilan pengemudi adalah dari responden pengguna bis dan kereta api sebesar $71,4 \%$ dan $66,7 \%$. Proporsi pilihan jawaban tidak puas 
tertinggi dari responden pengguna angkot adalah atribut kenyamanan stasiun/halte $(58,7 \%)$.

Data tersebut menunjukkan bahwa atribut kemudahan akses, atribut moda dan atribut keterampilan pengemudi adalah atribut yang memuaskan menurut persepsi responden, sedangkan atribut yang paling tidak memuaskan adalah atribut kebersihan dan kenyamanan stasiun/halte.

Analisis dilakukan dengan metode Friedman-test (Siegel, 1992). Untuk menguji hipotesis keberadaan perbedaan penilaian untuk setiap atribut kualitas pelayanan moda angkutan publik. Hipotesis yang digunakan dalam uji ini adalah:

$\mathrm{H}_{0}$ : Tidak terdapat perbedaan penilaian responden antar atribut kualitas pelayanan moda angkutan publik.

$\mathrm{H}_{1}$ : Terdapat perbedaan penilaian responden antar atribut kualitas pelayanan moda angkutan publik.

Dari hasil analisis tingkat kepuasan menurut pengguna angkot dapat dilihat bahwa p-value yang didapatkan adalah lebih kecil dari tingkat signifikansi yang digunakan $(\alpha=0,05)$. Hasil ini menjelaskan bahwa responden menilai seluruh atribut kualitas pelayanan moda angkutan publik berbeda. Hal ini berarti setiap atribut memiliki pengaruh terhadap penilaian responden untuk menentukan kategori jawaban yang akan dipilih.

Responden pengguna bis menilai atribut kualitas pelayanan kondisi kendaraan, keamanan di kendaraan, dan tepat waktu adalah sangat tidak puas dengan proporsi 17,9\%. Sedangkan pengguna kereta api menilai atribut keramahan dan kemudahan biaya adalah sangat tidak puas. Dari hasil analisis tingkat kepuasan menurut pengguna angkutan publik bis dan kereta api dapat dilihat bahwa p-value yang didapatkan adalah lebih besar dari tingkat signifikansi yang digunakan $(\alpha=0,05)$. Hasil ini menjelaskan bahwa tidak terdapat perbedaan responden pengguna angkutan publik bis dan kereta api dalam menilai seluruh atribut kualitas pelayanan. Berdasarkan hasil tersebut dapat diartikan setiap atribut tidak memiliki pengaruh terhadap penilaian responden untuk menentukan kategori jawaban yang akan dipilih.

Dari hasil analisis tingkat kepuasan menurut pengguna taksi, Responden pengguna taksi menilai atribut kualitas pelayanan tepat waktu $(17,8 \%)$ adalah sangat tidak puas. Dari hasil analisis tingkat kepuasan menurut pengguna angkutan publik taksi dapat dilihat bahwa p-value yang didapatkan adalah lebih kecil dari tingkat signifikansi yang digunakan $(\alpha=0,05)$. Hasil ini menjelaskan bahwa terdapat perbedaan responden 
pengguna angkutan publik taksi dalam menilai seluruh atribut kualitas pelayanan. Analisis menunjukkan setiap atribut memiliki pengaruh terhadap penilaian responden untuk menentukan kategori jawaban yang akan dipilih.

Responden pengguna moda angkutan publik lainnya menilai atribut kualitas pelayanan kondisi stasiun/halte dan keamanan di kendaraan (27,3\%) adalah sangat tidak puas. Dari hasil analisis tingkat kepuasan menurut pengguna moda angkutan publik lainnya dapat dilihat bahwa $p$-value yang didapatkan adalah lebih kecil dari tingkat signifikansi yang digunakan $(\alpha=0,05)$. Hasil ini menjelaskan bahwa terdapat perbedaan responden pengguna angkutan publik lainnya dalam menilai seluruh atribut kualitas pelayanan. Hal ini berarti setiap atribut memiliki pengaruh terhadap penilaian responden untuk menentukan kategori jawaban yang akan dipilih. 
Tabel 7 Deskripsi Data Tingkat KepuasanMenurut Pengguna

\begin{tabular}{|c|c|c|c|c|c|c|c|c|c|c|c|c|c|c|c|c|c|c|c|c|}
\hline \multirow{3}{*}{$\begin{array}{l}\text { Atribut } \\
\text { Kualitas } \\
\text { Pelyanan }\end{array}$} & \multicolumn{20}{|c|}{ Proporsi (\%) } \\
\hline & \multicolumn{4}{|c|}{ Angkot } & \multicolumn{4}{|c|}{ Bis } & \multicolumn{4}{|c|}{ Kereta Api } & \multicolumn{4}{|c|}{ Taksi } & \multicolumn{4}{|c|}{ Lainnya } \\
\hline & $\begin{array}{l}\text { SP } \\
(\%)\end{array}$ & $\begin{array}{l}\mathbf{P} \\
(\%) \\
\end{array}$ & $\begin{array}{l}\text { TP } \\
(\%)\end{array}$ & $\begin{array}{l}\text { STP } \\
(\%) \\
\end{array}$ & $\begin{array}{l}\text { SP } \\
(\%)\end{array}$ & $\begin{array}{l}\mathbf{P} \\
(\%)\end{array}$ & $\begin{array}{l}\text { TP } \\
(\%)\end{array}$ & $\begin{array}{l}\text { STP } \\
(\%) \\
\end{array}$ & $\begin{array}{l}\text { SP } \\
(\%)\end{array}$ & $\begin{array}{l}\mathbf{P} \\
(\%) \\
\end{array}$ & $\begin{array}{l}\text { TP } \\
(\%) \\
\end{array}$ & $\begin{array}{l}\text { STP } \\
(\%) \\
\end{array}$ & $\begin{array}{l}\text { SP } \\
(\%) \\
\end{array}$ & $\begin{array}{l}\mathbf{P} \\
(\%)\end{array}$ & $\begin{array}{l}\text { TP } \\
(\%) \\
\end{array}$ & $\begin{array}{l}\text { STP } \\
(\%) \\
\end{array}$ & $\begin{array}{l}\text { SP } \\
(\%)\end{array}$ & $\begin{array}{l}\mathbf{P} \\
(\%) \\
\end{array}$ & $\begin{array}{l}\text { TP } \\
(\%)\end{array}$ & $\begin{array}{l}\text { STP } \\
(\%) \\
\end{array}$ \\
\hline $\begin{array}{l}\text { Kebersihan } \\
\text { Kendaraan } \\
\text { Kebersihan }\end{array}$ & 4,4 & 35,2 & 55,0 & 5,4 & 7,1 & 46,4 & 42,9 & 3,6 & 6,7 & 53,3 & 33,3 & 6,7 & 13,3 & 31,1 & 48,9 & 6,7 & 0 & 27,3 & 72,7 & 0,0 \\
\hline $\begin{array}{l}\text { Stasiun/Halte } \\
\text { Kondisi }\end{array}$ & 5,0 & 25,2 & 56,7 & 13,1 & 10,7 & 35,7 & 50,0 & 3,6 & 6,7 & 53,3 & 33,3 & 6,7 & 0,0 & 33,3 & 53,3 & 13,3 & 0 & 9,1 & 54,5 & 36,4 \\
\hline $\begin{array}{l}\text { Kendaraan } \\
\text { Kondisi }\end{array}$ & 5,0 & 35,9 & 54,0 & 5,0 & 10,7 & 46,4 & 25,0 & 17,9 & 6,7 & 60,0 & 26,7 & 6,7 & 8,9 & 40,0 & 44,4 & 6,7 & 0 & 45,5 & 45,5 & 9,1 \\
\hline $\begin{array}{l}\text { Stasiun/Halte } \\
\text { Kenyamanan }\end{array}$ & 2,3 & 32,6 & 56,7 & 8,4 & 3,6 & 53,6 & 35,7 & 7,1 & 6,7 & 53,3 & 33,3 & 6,7 & 0,0 & 37,8 & 55,6 & 6,7 & 0 & 18,2 & 54,5 & 27,3 \\
\hline $\begin{array}{l}\text { Kendaraan } \\
\text { Kenyamanan }\end{array}$ & 4,4 & 35,6 & 51,0 & 9,1 & 14,3 & 35,7 & 39,3 & 10,7 & 13,3 & 20,0 & 53,3 & 13,3 & 17,8 & 37,8 & 40,0 & 4,4 & 0 & 27,3 & 54,5 & 18,2 \\
\hline $\begin{array}{l}\text { Stasiun/Halte } \\
\text { Kemudahan }\end{array}$ & 2,0 & 32,2 & 58,7 & 7,0 & 7,1 & 46,4 & 39,3 & 7,1 & 0,0 & 46,7 & 46,7 & 6,7 & 2,2 & 35,6 & 55,6 & 6,7 & 0 & 18,2 & 63,6 & 18,2 \\
\hline $\begin{array}{l}\text { Rute } \\
\text { Kemudahan }\end{array}$ & 3,7 & 44,6 & 43,0 & 8,7 & 10,7 & 60,7 & 17,9 & 10,7 & 6,7 & 46,7 & 40,0 & 6,7 & 6,7 & 33,3 & 46,7 & 13,3 & 0 & 54,5 & 45,5 & 0,0 \\
\hline $\begin{array}{l}\text { Biaya } \\
\text { Keamanan di }\end{array}$ & 3,4 & 35,9 & 48,0 & 12,8 & 3,6 & 67,9 & 25,0 & 3,6 & 6,7 & 60,0 & 13,3 & 20,0 & 6,7 & 48,9 & 33,3 & 11,1 & 0 & 36,4 & 54,5 & 9,1 \\
\hline $\begin{array}{l}\text { Kendaraan } \\
\text { Keamanan di }\end{array}$ & 5,7 & 38,3 & 46,0 & 10,1 & 7,1 & 57,1 & 17,9 & 17,9 & 13,3 & 46,7 & 26,7 & 13,3 & 15,6 & 46,7 & 28,9 & 8,9 & 0 & 45,5 & 27,3 & 27,3 \\
\hline $\begin{array}{l}\text { Stasiun } \\
\text { Kemudahan }\end{array}$ & 4,4 & 35,2 & 51,0 & 9,4 & 7,1 & 42,9 & 35,7 & 14,3 & 0,0 & 40,0 & 46,7 & 13,3 & 0,0 & 55,6 & 35,6 & 8,9 & 0 & 27,3 & 54,5 & 18,2 \\
\hline $\begin{array}{l}\text { Akses } \\
\text { Keterampilan }\end{array}$ & 5,4 & 57,4 & 34,6 & 2,7 & 0,0 & 64,3 & 21,4 & 14,3 & 26,7 & 20,0 & 46,7 & 6,7 & 6,7 & 73,3 & 17,8 & 2,2 & 0 & 81,8 & 18,2 & 0,0 \\
\hline Pengemudi & 4,4 & 44,6 & 40,3 & 10,7 & 0,0 & 71,4 & 17,9 & 10,7 & 6,7 & 66,7 & 20,0 & 6,7 & 8,9 & 53,3 & 35,6 & 2,2 & 0 & 54,5 & 36,4 & 9,1 \\
\hline Tepat Waktu & 2,7 & 27,9 & 51,0 & 18,5 & 3,6 & 50,0 & 28,6 & 17,9 & 6,7 & 33,3 & 46,7 & 13,3 & 8,9 & 33,3 & 40,0 & 17,8 & 0 & 36,4 & 63,6 & 0,0 \\
\hline Keramahan & 2,7 & 41,3 & 48,7 & 7,4 & 3,6 & 67,9 & 17,9 & 10,7 & 13,3 & 40,0 & 26,7 & 20,0 & 11,1 & 48,9 & 35,6 & 4,4 & 0 & 36,4 & 54,5 & 9,1 \\
\hline Moda & 2,7 & 57,7 & 35,9 & 3,7 & 3,6 & 64,3 & 21,4 & 10,7 & 0,0 & 60,0 & 33,3 & 6,7 & 2,2 & 73,3 & 20,0 & 4,4 & 0 & 63,6 & 36,4 & 0,0 \\
\hline $\mathrm{N}$ & & & & 298 & & & & 28 & & & & 15 & & & & 45 & & & & 11 \\
\hline Chi-Square & & & & 27,151 & & & & 12,989 & & & & 13,993 & & & & 68,324 & & & & 40,495 \\
\hline Df & & & & 14 & & & & 14 & & & & 14 & & & & 14 & & & & 14 \\
\hline p-value & & & & $\mathbf{0 , 0 0 0}$ & & & & $\mathbf{0 , 5 2 7}$ & & & & 0,450 & & & & $\mathbf{0 , 0 0 0}$ & & & & $\mathbf{0 , 0 0 0}$ \\
\hline
\end{tabular}

Keterangan : $\quad \mathrm{SP}=$ Sangat Penting; $\mathrm{P}=$ Penting; $\mathrm{TP}=$ Tidak Penting; $\mathrm{STP}=$ Sangat Tidak Penting 
Analisis Kruskal Wallis dilakukan untuk mengetahui berdasarkan tingkat kepuasan, apakah terdapat perbedaan persepsi pengguna masing - masing moda angkutan publik terhadap atribut kualitas pelayanan publik. Hipotesis yang digunakan adalah:

$\mathrm{H}_{0}$ : Penilaian responden pada setiap atribut kualitas pelayanan antar moda angkutan publik adalah tidak berbeda.

$\mathrm{H}_{1}$ : Penilaian responden pada setiap atribut kualitas pelayanan antar moda angkutan publik adalah berbeda.

Hasil analisis menunjukkan bahwa p-value yang didapat dari hasil perhitungan lebih kecil dari tingkat signifikansi $(\alpha)$ yang digunakan, yaitu 0,05 . Berdasarkan analisis tersebut bahwa terdapat perbedaan persepsi pengguna masing - masing moda terhadap atribut kualitas pelayanan angkutan publik yaitu atribut kebersihan stasiun/halte, atribut kondisi stasiun/halte, atribut kemudahan biaya, dan atribut keramahan staf. Dengan demikian penilaian responden antar moda tentang tingkat kepuasan atribut kualitas pelayanan tidak terkait. Hasil penelitian juga menjelaskan bahwa perhatian terhadap atribut - atribut kualitas pelayanan tersebut adalah penting, karena sebagian atribut yang dianggap penting masih dinilai tidak memuaskan. Analisis lebih lanjut yang menunjukkan peran dari masing - masing atribut perlu dilakukan untuk menentukan prioritas perbaikan yang sesuai harapan pengguna.

Tabel 8 Analisis Persepsi Responden Antar Moda Terhadap Atribut Kualitas Pelayanan Berdasarkan Tingkat Kepuasan

\begin{tabular}{lrl}
\hline Atribut Kualitas Pelayanan & $\boldsymbol{P}$ - Value & Keterangan \\
\hline Kebersihan Kendaraan & 0,327 & $\mathrm{H}_{0}$ diterima \\
Kebersihan Stasiun/Halte & 0,007 & $\mathrm{H}_{0}$ ditolak \\
Kondisi Kendaraan & 0,427 & $\mathrm{H}_{0}$ diterima \\
Kondisi Stasiun/Halte & 0,028 & $\mathrm{H}_{0}$ ditolak \\
Kenyamanan Kendaraan & 0,058 & $\mathrm{H}_{0}$ diterima \\
Kenyamanan Stasiun/Halte & 0,157 & $\mathrm{H}_{0}$ diterima \\
Kemudahan Rute & 0,172 & $\mathrm{H}_{0}$ diterima \\
Kemudahan Biaya & 0,010 & $\mathrm{H}_{0}$ ditolak \\
Keamanan di Kendaraan & 0,089 & $\mathrm{H}_{0}$ diterima \\
Keamanan di Stasiun & 0,404 & $\mathrm{H}_{0}$ diterima \\
Kemudahan Akses & 0,216 & $\mathrm{H}_{0}$ diterima \\
Keterampilan Pengemudi & 0,071 & $\mathrm{H}_{0}$ diterima \\
Tepat Waktu & 0,226 & $\mathrm{H}_{0}$ diterima \\
Keramahan & 0,040 & $\mathrm{H}_{0}$ ditolak \\
Moda & 0,535 & $\mathrm{H}_{0}$ diterima \\
\hline
\end{tabular}

\subsection{Analisis Perbandingan Data Tingkat Kepentingan dan Kepuasan}

Metode Wilcoxon Signed Rank Test digunakan untuk membandingkan perbedaan penilaian responden terhadap tingkat kepentingan dan tingkat kepuasan dari atribut kualitas pelayanan moda angkutan publik. Menurut Siegel (1992) tes ini digunakan pada 
kasus sampel berhubungan, khususnya untuk mengetahui efektivitas suatu perlakuan (treatment) dan tentang arah perbedaan didalam setiap pasangan. Selain arah perbedaan juga memperhatikan besar (magnitude) perbedaan tiap pasangan. Melalui tes ini bisa diperoleh informasi tentang perbandingan antar anggota pasangan (lebih besar atau lebih kecil) atau tanda selisih observasi pada setiap pasangan dan membuat rangking selisih tersebut dari urutan harga absolutnya. Artinya selain membuat penilaian tentang selisih diantara anggota pasangan juga membuat penilaian tentang dua skor yang timbul dari setiap dua pasangan. Tingkat signifikansi yang digunakan $(\alpha)$ adalah 0,05 . Hipotesis yang diuji pada metode Wilcoxon Signed Rank Test adalah:

Ho : Distribusi frekuensi relatif antara tingkat kepentingan dan kepuasan adalah identik.

Ha : Distribusi frekuensi relatif antara tingkat kepentingan dan kepuasan tidak identik.

Tabel 9 Hasil Tes Wilcoxon Signed Rank Test

\begin{tabular}{lcccrc}
\hline \multicolumn{1}{c}{ Aspek } & $\begin{array}{c}\text { Mean } \\
\text { Rank }\end{array}$ & $\begin{array}{c}\text { Total } \\
\text { Rank }\end{array}$ & $\mathbf{Z}$ & $\boldsymbol{p}$-value & $\mathbf{H}_{\mathbf{0}}$ \\
\hline Kebersihan Kendaraan & 158,0 & 48336,0 & $-15,422$ & 0,000 & Ditolak \\
Kebersihan Stasiun/Halte & 165,4 & 52277,5 & $-15,559$ & 0,000 & Ditolak \\
Kondisi Kendaraan & 156,1 & 46998,0 & $-15,262$ & 0,000 & Ditolak \\
Kondisi Stasiun/Halte & 147,4 & 41563,0 & $-14,715$ & 0,000 & Ditolak \\
Kenyamanan Kendaraan & 160,3 & 50025,5 & $-15,561$ & 0,000 & Ditolak \\
Kenyamanan Stasiun/Halte & 156,2 & 47482,5 & $-15,389$ & 0,000 & Ditolak \\
Kemudahan Rute & 146,8 & 40079,0 & $-14,318$ & 0,000 & Ditolak \\
Kemudahan Biaya & 148,6 & 41319,5 & $-14,333$ & 0,000 & Ditolak \\
Keamanan di Kendaraan & 169,5 & 56789,0 & $-16,177$ & 0,000 & Ditolak \\
Keamanan di Stasiun & 167,4 & 54576,0 & $-15,923$ & 0,000 & Ditolak \\
Kemudahan Akses & 132,5 & 33394,0 & $-13,936$ & 0,000 & Ditolak \\
Keterampilan Pengemudi & 157,0 & 47261,5 & $-15,037$ & 0,000 & Ditolak \\
Tepat Waktu & 164,9 & 53428,5 & $-15,839$ & 0,000 & Ditolak \\
Keramahan & 149,2 & 42231,0 & $-14,687$ & 0,000 & Ditolak \\
Moda & 126,6 & 30245,0 & $-13,525$ & 0,000 & Ditolak \\
\hline
\end{tabular}

Tabel 9 menunjukkan hasil dari metode Wilcoxon Signed Rank Test. Hasil analisis menunjukkan bahwa seluruh hipotesis $\mathrm{H}_{0}$ ditolak, artinya distribusi frekuensi relatif kedua populasi adalah tidak identik. Hal ini dapat diartikan bahwa responden merasa tidak puas dengan kualitas pelayanan atribut kualitas pelayanan yang dianggap penting.

\subsection{Analisis Tingkat Kepentingan - Kepuasan}

Metode analisis tingkat kepentingan-kepuasan ini digunakan untuk mengevaluasi prioritas pilihan atau komponen yang harus dimiliki suatu sistem pelayanan. Data yang

Atribut Kualitas Pelayanan Angkutan Publik Di Kota Bandung 
digunakan adalah data persepsi masyarakat tentang tingkat kepentingan dan tingkat kepuasan, dimana yang digunakan adalah total jumlah responden yang memilih "sangat penting", "penting", "sangat puas", dan "puas". Hasil dari analisis tingkat kepentingan kepuasan disajikan pada Tabel 10.

Tabel 10 menunjukkan atribut paling penting bagi responden adalah kebersihan kendaraan, kenyamanan kendaraan, keamanan di kendaraan dan tepat waktu dengan masing-masing proporsi $99,80 \%$. Peringkat kedua dan ketiga untuk tingkat kepentingan adalah atribut kebersihan stasiun/halte, kondisi kendaraan, keamanan di stasiun dan moda (masing - masing 98,80\%) dan kemudahan akses $(98,10 \%)$.

Atribut yang dianggap responden paling tidak penting adalah kondisi stasiun/halte $(96,00 \%)$. Peringkat pertama untuk tingkat kepuasan adalah kemudahan akses dengan proporsi $(64,80 \%)$. Atribut moda cukup memuaskan responden karena aspek ini berada di peringkat kedua dengan proporsi $62,50 \%$. Responden juga merasa puas dengan keterampilan pengemudi $(53,30 \%)$ dan kemudahan rute $(49,60 \%)$ yang berada di peringkat 3 dan 4. Kebersihan Stasiun/Halte merupakan aspek yang paling tidak memuaskan dengan proporsi $32,30 \%$.

Tabel 10 Proporsi dan Peringkat untuk Tingkat Kepentingan, Tingkat Kepuasan, dan Tingkat Kepentingan-Kepuasan

\begin{tabular}{lcrrrrrr}
\hline \multirow{2}{*}{\multicolumn{1}{c}{ Atribut }} & \multirow{2}{*}{ Kode } & \multicolumn{2}{c}{ Kepentingan } & \multicolumn{2}{c}{ Kepuasan } & \multicolumn{2}{c}{ I-S } \\
\cline { 3 - 8 } & & Proporsi & Rank & Proporsi & Rank & Proporsi & Rank \\
\hline Kebersihan Kendaraan & $\mathrm{A}$ & 99,80 & 1 & 41,50 & 10 & 58,50 & 5 \\
Kebersihan Stasiun/Halte & $\mathrm{B}$ & 98,80 & 2 & 32,30 & 14 & 67,70 & 1 \\
Kondisi Kendaraan & $\mathrm{C}$ & 98,80 & 2 & 44,00 & 8 & 56,00 & 7 \\
Kondisi Stasiun/Halte & $\mathrm{D}$ & 96,00 & 7 & 37,30 & 11 & 62,70 & 4 \\
Kenyamanan Kendaraan & $\mathrm{E}$ & 99,80 & 1 & 41,80 & 9 & 58,20 & 6 \\
Kenyamanan Stasiun/Halte & $\mathrm{F}$ & 97,80 & 4 & 36,00 & 12 & 64,00 & 3 \\
Kemudahan Rute & $\mathrm{G}$ & 97,00 & 5 & 49,60 & 4 & 50,40 & 11 \\
Kemudahan Biaya & $\mathrm{H}$ & 96,60 & 6 & 44,80 & 7 & 55,20 & 8 \\
Keamanan di Kendaraan & $\mathrm{I}$ & 99,80 & 1 & 48,10 & 5 & 51,90 & 10 \\
Keamanan di Stasiun & $\mathrm{J}$ & 98,80 & 2 & 41,80 & 9 & 58,20 & 6 \\
Kemudahan Akses & $\mathrm{K}$ & 98,10 & 3 & 64,80 & 1 & 35,20 & 14 \\
Keterampilan Pengemudi & $\mathrm{L}$ & 98,80 & 2 & 53,30 & 3 & 46,70 & 12 \\
Tepat Waktu & $\mathrm{M}$ & 99,80 & 1 & 34,10 & 13 & 65,90 & 2 \\
Keramahan & $\mathrm{N}$ & 97,80 & 4 & 47,80 & 6 & 52,20 & 9 \\
Moda & $\mathrm{O}$ & 98,00 & 2 & 62,50 & 2 & 37,50 & 13 \\
\hline
\end{tabular}

Keterangan: IS= Importance Satisfaction 
Hasil analisis tingkat kepentingan - kepuasan menunjukkan bahwa kebersihan stasiun/halte $(67,70 \%)$, tepat waktu $(65,90 \%)$, dan kenyamanan stasiun/halte $(64,00 \%)$ merupakan tiga atribut yang paling membutuhkan perbaikan. Hal ini dapat dianggap wajar untuk segera diperbaiki karena pengguna hampir tidak pernah menunggu angkutan publik di halte/stasiun dengan alasan kebersihan dan kenyamanan. Sedangkan atribut ketepatan waktu perlu diperbaiki karena kebiasaan supir angkutan publik yang sering berhenti di sembarang tempat dengan waktu yang lama untuk menunggu penumpang lain. Atribut yang dianggap responden paling baik adalah kemudahan akses $(35,20 \%)$, dikarenakan angkutan publik yang sering dijumpai terutama jenis angkot yang memiliki jumlah armada yang banyak sehingga memudahkan pengguna untuk mengaksesnya.

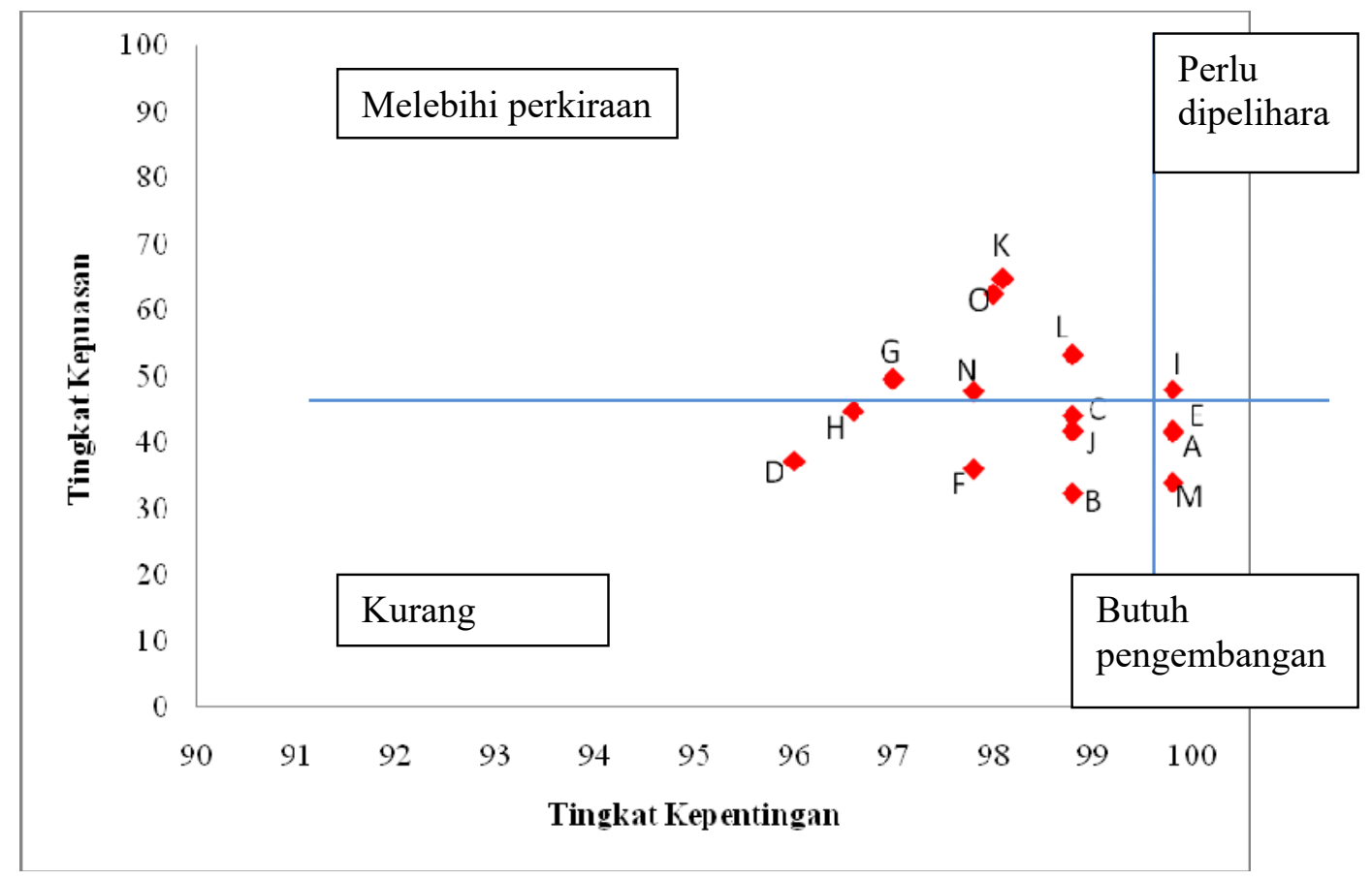

Gambar 2 Diagram kategori tingkat kepentingan dan kepuasan

Gambar 2 menunjukkan diagram hubungan antara tingkat kepentingan dan tingkat kepuasan. Tingkat kepentingan berada di sumbu $\mathrm{X}$ dan tingkat kepuasan berada di sumbu Y. Pada diagram tersebut terdapat empat kategori, yaitu perlu untuk dipelihara, melebihi perkiraan, kurang penting, dan membutuhkan pengembangan. Atribut yang termasuk dalam kategori perlu dipelihara adalah kemananan di kendaraan dan keterampilan pengemudi. Atribut yang termasuk dalam kategori kurang penting adalah kondisi stasiun/halte, kenyamanan stasiun/halte, dan kemudahan biaya. Atribut 
kebersihan kendaraan, kebersihan stasiun/halte, kondisi fisik kendaraan, kenyamanan di dalam kendaraan, keamanan dalam stasiun/halte, dan ketepatan waktu berada dalam kategori perlu pengembangan. Atribut yang masuk dalam kategori melebihi perkiraan adalah kemudahan mendapat informasi rute, kemudahan mengakses angkutan umum, keramahan staf, dan kemudahan mendapatkan moda.

\section{PEMBAHASAN}

Studi tentang persepsi pengguna angkutan perkotaan di kota Bandung dengan Importance Performance Analysis method yang dilakukan oleh Marioen (2013) akan memberikan hasil urutan prioritas atribut - atribut yang perlu diperbaiki. Hasil Importance Performance Analysis diperoleh urutan prioritas atribut kinerja pelayanan yang penting untuk diperbaiki yaitu kenyamanan saat berada di dalam kendaraan, kepatuhan dalam penerapan tarif, waktu operasi angkot dalam satu hari, tidak ada gangguan kenyamanan dari penumpang lain, waktu perjalanan, kemudahan mencapai tempat pemberhentian, keramahan dan kesopanan supir.

Aryandi (2012) menggunakan metode analisis deskriptif dan Importance Performance Analysis method untuk mengetahui tingkat kepuasan pengguna kereta api komuter Bandung - Cicalengka terhadap pelayanan yang diberikan oleh PT. KAI DAOP II Bandung. Hasil analisis deskriptif terhadap kuesioner menunjukkan bahwa mayoritas pengguna kereta api komuter adalah pelajar/mahasiswa sebesar (54\%), mayoritas tingkat pendapatan rata-rata per bulan responden $>\operatorname{Rp} 1.500 .000$,-per bulan yaitu sebesar 43\%, sedangkan sebagian besar tujuan perjalanan adalah sekolah dan kuliah (54\%), kendaraan yang digunakan pengguna menuju stasiun adalah sepeda motor (40\%), serta kendaraan yang digunakan menuju tujuan akhir adalah angkutan kota (68\%). Sedangkan atribut yang memerlukan perbaikan menurut pengguna kereta api yaitu atribut keleluasaan ketika berada didalam kereta api, atribut ketersediaan udara/sirkulasi didalam gerbong kereta api, atribut keamanan didalam kereta api, atribut ketepatan waktu kedatangan, atribut ketepatan waktu keberangkatan, atribut waktu tunggu kedatangan kereta api, atribut kebersihan didalam kereta api, dan atribut ketersediaan papan informasi jadwal.

Dalam studi penelitian Supriatna (2013) terhadap evaluasi kinerja pelayanan Trans Metro Bandung (Koridor II) di kota Bandung dengan menggunakan Importance Performance Analysis menghasilkan penilaian kinerja pelayanan berupa persepsi dan preferensi terhadap kinerja pelayanan TMB. Evaluasi yang didapat yaitu persepsi aspek keamanan pengguna semuanya menilai baik dan preferensinya semua pengguna menilai penting, aspek keselamatan pengguna menilai baik dan preferensi pengguna menilai 
sangat penting, persepsi aspek kenyamanan pengguna menilai baik dan preferensinya pengguna menilai sangat penting, persepsi aspek keterjangkauan pengguna menilai baik dan preferensinya pengguna menilai sangat penting, persepsi aspek kesetaraan pengguna menilai baik dan preferensinya pengguna menilai sangat penting, dan persepsi aspek keteraturan pengguna menilai baik dan preferensinya pengguna menilai sangat penting.

Dalam studi penelitian kualitas pelayanan halte Trans Metro Bandung Gultom (2011) menggunakan metode Importance-Satisfaction Analysis. Hasil analisis yang diperoleh menunjukkan bahwa aspek yang paling membutuhkan pengembangan adalah kebersihan halte, fasilitas pendukung di sekitar halte, dan tangga halte. Aspek yang perlu dipelihara adalah aksesibilitas, keselamatan, keamanan, pelayanan petugas, atap, dan tempat duduk. Lampu penerangan, area khusus perokok, dan ketersediaan informasi termasuk dalam kategori kurang penting. Pada akhirnya penelitian ini menunjukkan bahwa tingkat kepentingan yang tinggi terhadap aspek-aspek kualitas halte tidak diikuti oleh tingkat kepuasan yang tinggi juga.

Dalam penelitian ini diterapkan metode Importance-Satisfaction Analysis. Tujuan utama dari penelitian ini adalah untuk menganalisis kualitas pelayanan angkutan publik menurut sudut pandang pengguna angkutan publik ditinjau dari tingkat kepentingan dan kepuasan. Hasil analisis tingkat kepentingan dan kepuasan menunjukkan aspek kebersihan kendaraan, kebersihan stasiun/halte, kondisi fisik kendaraan, kenyamanan di dalam kendaraan, keamanan dalam stasiun/halte, dan ketepatan waktu berada dalam kategori perlu pengembangan.

Studi - studi kualitas pelayanan angkutan publik menurut persepsi pengguna berdasarkan tingkat kepentingan dan kepuasan terhadap kualitas pelayanan angkutan publik pada umumnya memiliki tujuan yang sama. Salah satu tujuan strategis adalah untuk menarik pengguna baru angkutan publik dan mengurangi jaringan transportasi pengguna mobil pribadi atau motor. Secara keseluruhan pengguna angkutan publik memiliki persepsi yang berbeda terhadap atribut - atribut kualitas pelayanan. Pengguna angkutan publik memiliki tingkat kepentingan yang tinggi terhadap atribut kualitas pelayanan tapi tidak mendapatkan kepuasan dari pelayanan angkutan publik. Mereka yang memiliki akses kendaraan pribadi diharapkan untuk mempertimbangkan manfaat menggunakan angkutan publik dibandingkan dengan kenyamanan mengemudi. Jenis penelitian yang berkaitan dengan persepsi pengguna diuji dari indikator kualitas pelayanan angkutan publik, sangat berguna untuk pengelola sistem dan pengambil keputusan, karena hal ini menunjukkan faktor - faktor yang harus ditindak lanjuti 
didalam rangka untuk meningkatkan kualitas pelayanan angkutan publik dan membuatnya berkelanjutan.

\section{KESIMPULAN DAN SARAN}

Berdasarkan analisis yang telah dilakukan, maka diperoleh beberapa kesimpulan sebagai berikut: Hasil analisis terhadap kualitas pelayanan menunjukkan bahwa pengguna angkutan publik memiliki tingkat kepentingan yang tinggi terhadap atribut - atribut kualitas pelayanan angkutan publik tetapi kenyataannya tidak memuaskan. Hal ini dapat diartikan bahwa pengguna merasa tidak puas dengan atribut - atribut kualitas pelayanan angkutan publik yang dianggap penting dan sangat penting. Importance-Satisfaction Analysis menunjukkan bahwa atribut yang paling membutuhkan pengembangan adalah kebersihan kendaraan, kebersihan stasiun/halte, kondisi fisik kendaraan, kenyamanan di dalam kendaraan, keamanan dalam stasiun/halte, dan ketepatan waktu. Atribut yang termasuk dalam kategori perlu dipelihara adalah kemananan di kendaraan dan keterampilan pengemudi. Atribut yang termasuk dalam kategori kurang penting adalah kondisi stasiun/halte, kenyamanan stasiun/halte, dan kemudahan biaya. Atribut yang masuk dalam kategori melebihi perkiraan adalah kemudahan mendapat informasi rute, kemudahan mengakses angkutan umum, keramahan staf, dan kemudahan mendapatkan moda.

Agar tercapai tingkat kepuasan pengguna yang sesuai dengan tingkat kepentingan yang tinggi maka sangat diharapkan adanya koordinasi antara pihak penyelenggara angkutan publik baik swasta maupun pemerintah (Dinas Perhubungan kota Bandung, PT KAI DAOP 2 Bandung, Perum DAMRI, UPT TMB) dalam melakukan perbaikan pada aspek - aspek kualitas pelayanan yang dianggap penting. Selanjutnya perlu dilakukan studi kualitas pelayanan angkutan publik ditinjau dari sisi pemilik atau penyelenggara agar tercapai pelayanan yang memuaskan bagi pengguna angkutan publik.

\section{DAFTAR PUSTAKA}

1. Aryandi, H. (2012), “Analisa Tingkat Kepuasan Pengguna Kereta Api Diesel Patas Bandung - Cicalengka”, Skripsi, Teknik Planalogi Fakultas Teknik, UNPAS, Bandung.

2. Black, A. (1995), Urban Mass Transportation Planning. Int ed. McGraw-Hill series in transportation. New York. 
3. Dragana, G., Ivan, I., Jadranka, J., and Vladimir, D. (2013), "Customer Perception Of Service Quality In Public Transport", Faculty of Transport and Traffic Engineering, University of Belgrade, Belgrade.

4. Gultom, H. S. A. (2011), "Kualitas Pelayanan Halte Trans Metro Bandung", Skripsi, Program Studi Teknik Sipil Faktultas Teknik-UNPAR. Bandung.

5. Indrawan, M. A. S. (2009), “Penentuan Prioritas Kualitas Pelayanan Transportasi Publik menurut Pengguna”, Skripsi, Program Studi Teknik Sipil faktultas TeknikUniversitas Katolik Parahyangan. Bandung.

6. Israel, G. D. (1992), Determining Sample Size, University of Florida, USA.

7. Joewono, T. B., and Kubota, H. (2005), “A User Perception Model Concerning Safety And Security Of Paratransit Services In Bandung, Indonesia”, Jurnal Transportasi Vol. 5 No. 1 Juni 2005.

8. Marioen, N. S. R. (2013), “Analisis Kinerja Pelayanan Angkutan Perkotaan Di Kota Bandung Jenis Mobil Penumpang Umum Menurut Persepsi Pengguna (Studi Kasus: Trayek Panyileukan - Sekemirung)", Skripsi, Program Studi Teknik Sipil - Fakultas Teknik Sipil Dan Lingkungan, Institut Teknologi Bandung.

9. Parasuraman, A., Berry L.L., and Zeithaml, V.A. (1990). Delivering Quality Service: Balancing Customer Perception and Expectation. Free Press, New York.

10. Supriatna, Y. (2013), "Evaluasi Kinerja Pelayanan TMB Dari Sisi Pengguna Dengan Menggunakan Dengan Menggunakan Analisis GAP (Studi Kasus: Koridor II Cicaheum - Cibeureum Pp)", Skripsi, UNIKOM, Bandung. 